WSRC-RP-91-551

\title{
DEEP DRILLING PHASE OF THE PEN BRANCHĀ FAULT PROGRAM (U)
}

by

A. Stieve

Westinghouse Savannah River Company

Savannah River Site

Aiken, South Carolina 29808

A Technical Report for publication

This report was prepared in connection with work done under Contract No. DE-AC09-89SR18035 with the U.S. Department of Energy. By acceptance of this paper, the publisher and/or recipient acknowledges the U.S. Government's right to retain a nonexclusive, royalty-free license in and to any copyright covering this paper, along with the right to reproduce and to authorize others to reproduce all or part of the copyrighted paper. 


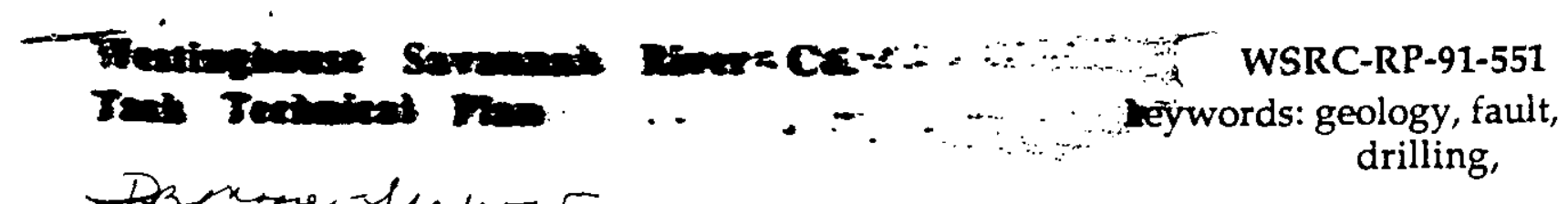

D. B. Moore-Shedrow, Section Manager

Authorized Derivative Classifer

May 15, 1991

To: $\quad$ D. S. Kaback, group manager

From: A. Stieve, task leader GJf.

TITLE: DEEP DRILLING PHASE OF THE PEN BRANCH FAULT PROGRAM.

Introduction

This activity is one element of the Pen Branch Fault Program. The effort will consist of three tasks: the extension of wells PBF-7 and PBF-8 into crystalline basement, geologic and drilling oversight during drilling operations, and the lithologic description and analysis of the recovered core.

The first phase of drilling under the Pen Branch Fault program included 6 holes cored to basement. As task 1 of the current drilling activity, two of those holes will be deepened to approximately $3000 \mathrm{ft}$ below the surface. The current drilling program is designed to intersect the Pen Branch fault as it is expressed in the crystalline basement. This will provide more control on the geometry as well as the movement history of the fault and on the location and geometry of the Dunbarton basin. The drilling program addresses the association of the Pen Branch fault with older fault systems such as the fault that formed the basin in the Triassic.

Independent technical oversight will be on site to document drilling activities at well site PBF-7 and -8 and provide geological services. Registered South Carolina geologists will be required for oversight. They will ensure that proper coring, logging, sample handling, storage, and labeling procedures are followed.

The third task will be the core description and report. This will be prepared by the oversight subcontractor after completion of the drilling. It will be subject to review by the ESS subcontractor technical representative.

\section{Discussion}

The SRS is located on the Atlantic Coastal Plain, which is an essentially flat-lying, undeformed wedge of unconsolidated marine and fluvial sediments. The sediments are stratified sand, clay, limestone, and gravel that dip gently seaward and range in age from Late Cretaceous to Recent. The sedimentary sequence thickens from zero at the Fall Line to more than 4,000 feet at the coast. There are about 600 to 1,200 feet-of Coastal Plain sediments at SRS. The Coastal Plain section is divided into several groups based principally on age and lithology. 
To: $\quad$ D. S. Kaback, group manager

From: $\quad$ A. Stieve, task leader $\quad$ u $7 . /$.

\section{TITLE: DEEP DRILLING PHASE OF THE PEN BRANCH FAULT PROGRAM.}

\section{Introduction}

This activity is one element of the Pen Branch Fault Program. The effort will consist of three tasks: the extension of wells PBF-7 and PBF-8 into crystalline basement, geologic and drilling oversight during drilling operations, and the lithologic description and analysis of the recovered core.

The first phase of drilling under the Pen Branch Fault program included 6 holes cored to basement. As task 1 of the current drilling activity, two of those holes will be deepened to approximately $3000 \mathrm{ft}$ below the surface. The current drilling program is designed to intersect the Pen Branch fault as it is expressed in the crystalline basement. This will provide more control on the geometry as well as the movement history of the fault and on the location and geometry of the Dunbarton basin. The drilling program addresses the association of the Pen Branch fault with older fault systems such as the fault that formed the basin in the Triassic.

Independent technical oversight will be on site to document drilling activities at well site PBF-7 and -8 and provide geological services. Registered South Carolina geologists will be required for oversight. They will ensure that proper coring, logging, sample handling, storage, and labeling procedures are followed.

The third task will be the core description and report. This will be prepared by the oversight subcontractor after completion of the drilling. It will be subject to review by the ESS subcontractor technical representative.

\section{Discussion}

The SRS is located on the Atlantic Coastal Plain, which is an essentially flat-lying, undeformed wedge of unconsolidated marine and fluvial sediments. The sediments are stratified sand, clay, limestone, and gravel that dip gently seaward and range in age from Late Cretaceous to Recent. The sedimentary sequence thickens from zero at the Fall Line to more than 4,000 feet at the coast. There are about 600 to 1,200 feet of Coastal Plain sediments at SRS. The Coastal Plain section is divided into several groups based principally on age and lithology. 
Beneath the Coastal Plain section is a pre-Cretaceous unconformity that developed on a basement consisting of two geologic terranes; 1) Triassic-Jurassic rift basin, the Dunbarton basin, filled with lithified terrigenous and lacustrine sediments with minor amounts of mafic volcanic and intrusive rock (Marine, 1974; Marine and Siple, 1974) and 2) crystalline terrane of metamorphosed sedimentary and igneous rock that may range in age from Precambrian to late Paleozoic.

The Pen Branch fault is a recently discovered feature in the Coastal Plain and basement at SRS. A program has been underway since January 1989 to evaluate the ability of this fault to release seismic energy (earthquake energy).

Because the PBF is located near operating nuclear facilities, public perception and federal regulations indicate that a thorough investigation of the fault is appropriate to determine whether any seismic hazard exists.

A phased program has been developed to investigate the PBF and to satisfy NRC regulatory quidelines represented in 10 CFR 100 Appendix $\mathrm{A}$. The program will be conducted over a period of 3 years. The objectives of the PBF program are to fully characterize the nature of the PBF.

Siting of nuclear reactors, as regulated in Appendix A of 10 CFR 100, requires identification of any faults with seismic potential in the region and in the vicinity of the nuclear facility. SRS is not required to comply with NRC regulations, but does follow the regulations as guidelines for siting and safety analysis of SRS facilities. SRS has used four criteria to establish the specific objectives for the PBF program.

The four criteria outlined in 10 CFR 100 Appendix A which define a "capable fault" as a fault likely to release large amounts of accumulated elastic strain energy as earthquakes include:

- criterion of recent or continual movement

- criterion of direct relation to "felt" earthquakes

- criterion of direct relationship to a known capable fault.

- criterion given for non-capability for faults that are associated with geologically very old structures

Due to the complexity and sensitivity of the PBF investigation program, a review committee of outside experts has been established (ESAC). They assist us in program design and data interpretation. Major program elements are carried out with the advice and consent of this group. Representation comes from academe, industry, and government. 


\section{Task Description}

\section{Customers}

\section{Environmental Sciences Section}

\section{Task deliverables}

a) Recovered core from the drill holes stored in suitable core boxes provided by the drilling subcontractor.

b) Daily log of drilling operations

c) Continuous core description describing metamorphic rocks, clastic rocks, possible fault zones, fault rock textures, and hydrothermal alteration.

d) Final summary report

\section{Task requirements}

a) For the oversight of drilling operations; a registered South Carolina geologist experienced with crystalline metamorphic rock and the criteria for recognizing faults and fault rock textures.

b) For drilling operations; a South Carolina certified driller, drill rigs with the proper support equipment, and support personnel.

c) Drillers are to be familiar with and adhere to all safety and procedural requirements as outlined in DPSOP-254, South Carolina Well Standards and Regulations R. 61-71, and OSHA 29 CFR Part 1910. Company management personnel must have 5 or more years experience in the drilling industry and drill rig operators must have a minimum of 2 years experience. Resumes of all drillers and supervision anticipated to work at SRS must be included in the bid proposal.

\section{Task prerequisites}

key parameters: qualified drillers, qualified oversight, appropriate drill rigs and support equipment

\section{accuracy of measurements: NA}

\section{Task Activities}

1) Wireline core 2 boreholes from a depth of approximately $1000 \mathrm{ft}$. to $3000 \mathrm{ft}$.

2) Recovering core from the borehole and storing in suitable core boxes with elevation markings indicate for the top and bottom.

3) Borehole deviation measurements done every $200 \mathrm{ft}$. to determine the lateral and vertical position of the hole.

4) Oversight shall supervise the drill crew to insure proper operating procedure.

5) Oversight shall maintain a daily log of drilling operations.

6) Oversight shall maintain a continuous core log description.

7) Oversight shall be responsible for the final summary report. 


\section{References}

Code of Federal Regulations, 10 CFR 100 Appendix A, 1982, Seismic and geologic siting criteria for nuclear power plants: Office of the Federal Register, National Archives and Records Administration.

Marine, 1. W. , 1976, Structural and sedimentational model of the buried Dunbarton Triassic basin, South Carolina and Georgia, DP-MS-74-39, Savannah River Site, Aiken, South Carolina.

Marine, I. W., 1974, Geohydrology of a Buried Triassic Basin at Savannah River Plant, South Carolina: AAPG Bull. v. 58 p. 1825-1837.

Marine, I.W., and Siple, G.E., 1974, Buried Triassic basin in the central Savannah River area, South Carolina and Georgia: Geological Society of America Bulletin, v. 85, p.311-320.

Marine,I. W., 1974b, Geohydrology of the buried Triassic basin at the Savannah River Plant, Groundwater, vol12, 96 pp.

Price, V., Steele, J., Stieve, A., 1989, Pen Branch Fault Investigation Program Plan, ESS-SRL-89-395.

Siple, G.E., 1967, Geology and ground water of the Savannah River Plant and vicinity, South Carolina: U.S. Geological Survey Water Supply Paper No. 1841,113 p.

Snipes, D. S., Fallaw, W. C., Price, Jr., V., 1989, The Pen Branch Fault:

Documentation of Late Cretaceous-Tertiary faulting in the Coastal Plain of South Carolina (U), Westinghouse-SRS, DP-MS-88-219.

\section{Signatures}

Alice stieve Whis 2. Dtient

Task Leader

$\frac{\text { Nown \&. Kaback }}{\text { Group Manager }}$

DBrene-Shedurer

Section Manager

$\overline{\text { Cognizant Quality Function }}$

\section{$6 / 17 / 91$}

\section{Date}

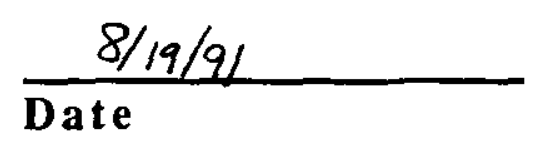

$\frac{8 / 21 / 91}{\text { Date }}$ 
TASK QA PILAN

Task Title: Deep Drilling for the PBF

Task Leader: Alice Stieye

Key Parameter Listing (number each parameter and enter number on checklist):

Qualifications of drillers, qualified oversight, appropriate drill rigs.

Additional comments (explanation of exceptions or additions to existing procedures):

Documents Requiring Customer Approval:

final report from drilling oversight

Records:

- Program Plan or Task Assignment

SRL-ESS-89-395

Task Technical Plan

WSRC-RP-91-551

SRI-ESS-91-636

- Uniquely Identified Notebooks

- Results of Idenpendent Technical Reviews

- Supporting Documentation

- List any other anticipated records Final report

Approvals:

Alice stieve

alis ptoin

rask Leader

Date

$\frac{\text { Nawn H. Kaback }}{\text { Group Manager }}$

$\frac{8 / 5 / 91}{\text { Date }}$

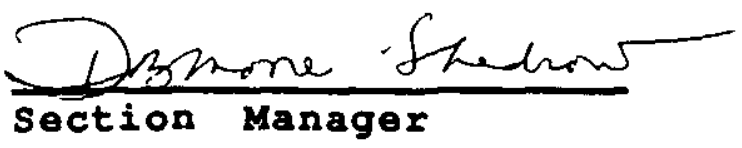

$\frac{8 / 22 / 91}{\text { Date }}$

$\frac{S \cdot R \cdot 2 g \text { L }}{\text { cognizant }}$

$\frac{\sin 6 / 2491}{\text { Date }}$ 
$S R L-E S S-9 F^{-636}$

1 ask QA Plan Checklist

Task Title: Deep Drilling

Task Leader: Alice Stieve

Organization

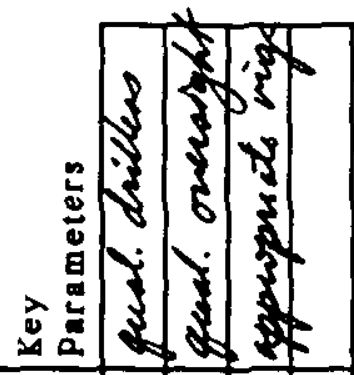

Program

NA

Design Control

NA

Procurement NA

$\mathrm{X}$

CP\&ET-QAIP-4\&7

Procedures

NA

CP\&ET-QAIP-5

Document Control

\begin{tabular}{l|l|l}
$\mathrm{X}$ & $\mathrm{X}$ & $\mathrm{X}$ \\
\hline
\end{tabular}

CP\&ET-QAIP-6

ID \& Control of Items

NA

CP\&ET-OAIP-8

M\&TE

NA

CP\&ET-QAIP-12

Handling, Storage, \& Shipping

NA

CP \& ET RALP

Nonconformance

\begin{tabular}{l|l|l}
$\mathrm{X}$ & $\mathrm{X}$ & $\mathrm{X}$ \\
\hline
\end{tabular}

CP\&ET-OAIP-15

Records

CP\&ET-QAIP-17

Software

NA

Note. The following OA criteria are NA

in addition to those indicated in the above

matrix: $9,10,11,14,16,18,19,20$ 